Part of Journal of Research of the National Bureau of Standards, Volume 19, December 1937

\title{
USE OF ARSENIOUS OXIDE IN THE STANDARDIZATION OF SOLUTIONS OF POTASSIUM PERMANGANATE
}

\author{
By Harry A. Bright
}

\section{ABSTRACT}

Values obtained in the standardization of $0.1 \mathrm{~N}$ potassium permanganate solutions by National Bureau of Standards' standard sample of arsenious oxide 83 , using potassium iodide or potassium iodate as a catalyst (Lang's procedure), have been compared to those obtained with sodium oxalate by the method of Fowler and Bright. The normalities found agreed to within 1 part in 3,000 which demonstrates the suitability of arsenious oxide as a direct primary standard in permanganimetry.

\section{CONTENTS}

Page

I. Introduction

II. Procedure for standardizing $0.1 \quad N$ potassium permanganate with arsenious oxide

1. Potentiometrically _.

2. Visually

III. References_.

\section{INTRODUCTION}

It is well known that the direct titration of trivalent arsenic with permanganate in dilute acid solutions is unsatisfactory, because the reaction does not proceed according to stoichiometric relations. R. Lang [3] has stated that a very small amount of potassium iodate or iodide acts as a catalyst to complete the reduction of manganese to the divalent state.

His data show satisfactory precision, and he apparently checked the accuracy of the procedure by means of iodine (through permanganate-iodide and thiosulphate), though this is not stated clearly, Kolthoff, Laitinen, and Lingane [2] compared the normality of 0.5 $N$ potassium permanganate determined by Lang's procedure with that found by direct potentiometric titration of potassium iodide with permanganate in very dilute acid solution. The factors obtained by the two methods agreed within 0.03 percent. Recently the author has made a careful comparison of Lang's procedure with the sodium oxalate procedure of Fowler and Bright [1] ${ }^{1}$ to determine whether the former is sufficiently accurate to permit the use of the National Bureau of Standards' standard sample 83 of arsenious oxide (now issued as an iodimetric standard) as a fundamental standard in permanganimetry.

\footnotetext{
${ }_{1}$ Numbers in brackets refer to the literature references at the end of this paper.
} 
The experimental details, in brief, were as follows: Weight burettes were used, and all weights were corrected to the vacuum standard. National Bureau of Standards' sodium oxalate sample 40c (purity taken as 99.95 percent) and arsenious oxide sample 83 (purity taken as 99.98 percent) were used. Both of these materials were dried for 1 hour at $105^{\circ} \mathrm{C}$ immediately before use. In the potentiometric titration the usual bright platinum-calomel electrode arrangement was used. Standardization with sodium oxalate was done as described by Fowler and Bright. With arsenious oxide Lang's procedure, as described in the next section, was used except that $0.3-$ to $0.6-\mathrm{g}$ samples were taken.

\section{PROCEDURE FOR STANDARDIZING $0.1 N$ PO'TASSIUM PERMANGANATE WITH ARSENIOUS OXIDE}

Accurately weigh approximately $0.25 \mathrm{~g}$ of the dried oxide and transfer to a $400-\mathrm{ml}$ beaker. Add $10 \mathrm{ml}$ of a cool 20 -percent solution of sodium hydroxide, free from oxidizing or reducing substances. Let stand for 8 to 10 minutes, stirring occasionally. When solution is complete, add $100 \mathrm{ml}$ of water, $10 \mathrm{ml}$ of hydrochloric acid (sp gr 1.18) and 1 drop of $0.0025 M$ potassium iodate or potassium iodide. The titration can be followed potentiometrically or visually.

\section{POTENTIOMETRICALLY}

Titrate with the permanganate solution to the maximum value of the ratio $(\Delta E ! \Delta V)$, change in potential per unit volume of solution added. Add the last 1 to $1.5 \mathrm{ml}$ dropwise, allowing equilibrium to be reached before the $\Delta E$ reading is taken. In the potentiometric titration the blank is negligible provided the reagents are free from interfering substances.

\section{VISUALLY}

Titrate with the permanganate solution until a faint-pink color persists for 30 seconds. Add the last 1 to $1.5 \mathrm{ml}$ dropwise, allowing each drop to become decolorized before the next is introduced. Determine the volume of permanganate required to duplicate the pink color of the end point. This is done by adding permanganate to a solution containing the same amounts of alkali, acid, and catalyst as were used in the test. The corrections should not amount to much more than $0.03 \mathrm{ml}$. The end point can also be taken with ferrous phenanthroline indicator. In this case, 1 drop of a $0.025 M$ solution of the indicator is added as the end point is approached. Permanganate is then slowly added until the pink color of the indicator changes to a very faint blue. The blank correction should average about $0.02 \mathrm{ml}$.

The normalities indicated for two approximately $0.1 \mathrm{~N}$ solutions of potassium permanganate are shown in table 1 . The data show that the recommended procedures yield results of a very satisfactory order of precision and that standardizations of permanganate solutions by the use of the National Bureau of Standards' standard samples of sodium oxalate $40 \mathrm{c}$ and arsenious oxide 83 should agree within 1 part in 3,000 . 
TABLE 1.--Comparison of the normality of approximately $0.1 \mathrm{~N} \mathrm{KMnO}_{4}$, as indicated by titration of $\mathrm{As}_{2} \mathrm{O}_{3}$ and $\mathrm{Na}_{2} \mathrm{C}_{2} \mathrm{O}_{4}$

\begin{tabular}{|c|c|c|c|c|}
\hline $\begin{array}{l}\text { Normality } \\
\text { by } \mathrm{As}_{2} \mathrm{O}_{3}\end{array}$ & $\begin{array}{c}\text { Number of } \\
\text { determina- } \\
\text { tions }\end{array}$ & $\begin{array}{c}\text { A verage } \\
\text { deviation } \\
\text { from mean }\end{array}$ & $\begin{array}{c}\text { Difference } \\
\text { from } \\
\mathrm{Na}_{2} \mathrm{C}_{2} \mathrm{O}_{4} \\
\text { value }\end{array}$ & Catalyst \\
\hline \multicolumn{5}{|c|}{ Series 1. Normality by $\mathrm{Na}_{2} \mathrm{C}_{2} \mathrm{O}_{4}=0.10015$ a } \\
\hline $\begin{array}{r}0.10016 \\
\text { b. } 10018 \\
.10019 \\
.10019\end{array}$ & $\begin{array}{l}3 \\
3 \\
2 \\
3\end{array}$ & $\begin{array}{c}\text { Percent } \\
0.022 \\
.029 \\
.002 \\
.028\end{array}$ & $\begin{array}{c}\text { Percent } \\
0.01 \\
.03 \\
.04 \\
.04\end{array}$ & $\begin{array}{l}\mathrm{KIO}_{3} \\
\mathrm{KIO}_{3} \\
\mathrm{KIO} \\
\mathrm{KI}\end{array}$ \\
\hline \multicolumn{5}{|c|}{ Series 2. Normality by $\mathrm{Na}_{2} \mathrm{C}_{2} \mathrm{O}_{4}=0.10391$ a } \\
\hline $\begin{array}{r}0.10387 \\
.10388 \\
.10390 \\
.10389\end{array}$ & $\begin{array}{l}1 \\
1 \\
4 \\
2\end{array}$ & $\begin{array}{l}.015 \\
.015\end{array}$ & $\begin{array}{l}0.04 \\
.03 \\
.01 \\
.02\end{array}$ & 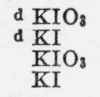 \\
\hline
\end{tabular}

a Normality as indicated by Fowler and Bright's method. In the first series the value is the average of 8 determinations (average deviation $=0.014$ percent), and in the second, the average of 7 determinations (average deviation $=0.010$ percent).

$0.6000 \mathrm{~g}$ of arsenious oxide used, all others $0.3000 \mathrm{~g}$.

- $\mathrm{KMnO}_{4}$ added slowly, about $7 \mathrm{ml}$ per minute.

d End point with orthophenanthroline.

\section{REFERENCES}

[1] Fowler and Bright, J. Research NBS 15, 493 (1935) RP843.

[2] Kolthoff, Laitinen, and Lingane, J. Am. Chem. Soc. 59, 429 (1937).

[3] Lang, Z. anal. Chem. 15\%, 197 (1926).

Washington, September 15, 1937. 